\title{
Isolasi Dan Uji Aktivitas Bakteri Penghasil Selulase Asal Tanah Kandang Sapi
}

\author{
Albert Sembiring 1 \\ ${ }^{1}$ Program Studi Agribisnis Hortikultura, Politeknik Wilmar Bisnis Indonesia, \\ Deli Serdang \\ ${ }^{1}$ Email: albertsembiring16@gmail.com
}

\begin{abstract}
Abstrak: Biomassa tanaman yang umumnya berasal dari limbah pertanian dapat ditransformasi menjadi produk yang bermanfaat dalam industri dan pertanian, seperti biotenol dan pupuk organik. Salah satu cara dalam mengkonversi selulosa menjadi pupuk organik adalah dengan memanfaatkan enzim selulase yang dihasilkan oleh bakteri. Penelitian ini bertujuan untuk memperoleh isolat bakteri penghasil selulase potensial yang berasal dari tanah sekitar kandang sapi di lingkungan IPB. Isolasi bakteri dilakukan dengan metode pengenceran bertingkat yang disebar pada media carboxy methyl cellulose $1 \%$ (CMC 1\%) yang diinkubasi selama 48 jam pada suhu $37^{\circ} \mathrm{C}$. Pengujian bakteri penghasil selulase dilakukan secara kualitatif dengan menotolkan bakteri terpilih di tengah media CMC $1 \%$ dengan penambahan pewarna congored 1\%. Dari hasil yang diperoleh terdapat tiga isolat bakteri yang mampu menghasilkan selulase yaitu KS 0.1, KS 0.7 dan KS 9.1 dengan indeks selulolitik tertinggi 1,33 pada isolat KS 0.1. Pengukuran aktivitas isolat KS 0.1 menggunakan metode spektrofometri DNS menunjukkan produksi aktivitas selulase tertinggi terdapat pada hari ke-1 dan terendah pada hari ke-8.
\end{abstract}

Kata Kunci: Bakteri, Selulose, Tanah Sekitar Kandang

Abstract: Plant biomass from waste agricultural can be transformed to useful like bioethanol and organic fertilizer in industry and agriculture using bacterial cellulase is one alternative to convert cellulose become organic fertilizer. This research had an objective to obtain potential bacterial cellulase isolated from the soil around of cowshed in Institut Pertanian Bogor. Bacteria were isolated from soil had used serial dilution that spread in $1 \%$ Carboxy Methyl Cellulose Medium (CMC 1\%) and it's incubated at $37^{\circ} \mathrm{C}$ for 48 hours. Qualitative test for bacteria producing cellulose was carried out by picking the selected colony in the centered of CMC medium with adding congo red $1 \%$. Based on the results were obtained three potential isolates could produce cellulose that were KS 0.1 , KS 0.7 and KS 9.1. The highest cellulolytic index is 1.33 that produced by KS 0.1 . The test quantitative activity of KS 0.1 using spectrophotometry method showed that the highest of enzyme activity at the first day and lowest eighth day during incubation period. Key Words: bacteria, cellulose, soil around of cowshed 
Selulosa merupakan polimer bahan organik jenis karbohidrat yang banyak ditemukan di alam terutama pada biomassa tanaman. Di dalam tanaman, selulosa adalah salah satu komponen penyusun dinding sel (35-50\%) (Saha, 2004) berfungsi untuk mempertahankan struktur dan bentuk tanaman yang disusun dari ikatan $\beta-1,4$ glikosidik yang stabil dan tidak mudah putus (Howard, 2003). Secara alami proses pembusukan biomassa tanaman baik yang berasal dari limbah pertanian atau limbah rumah tangga seperti kulit buah, tongkol jagung, sayur dan buah busuk, jerami padi, rumput terjadi dalam waktu yang cukup lama. Proses pembusukan ini dapat dipercepat dengan menggunakan bantuan bahan kimia atau juga biologis.

Pembusukan dengan bantuan biologis menjadi alternatif pilihan yang paling diminati mengingat dapat terjadinya pemakaian tak terkendali dari penggunaan bahan kimia yang dapat menimbulkan bahaya bagi kesehatan. Selulase adalah enzim kompleks yang terdiri dari eksoselulase, $\beta-1,4$ endoglukanse dan $\beta-1,4$ glukosidase yang dapat menghidrolisis selulosa menjadi glukosa, selobiosa dan selooligosakarida dengan memotong secara bertahap ikatan $\beta-1,4$ glikosida (Gerhatz, 1990), sehingga mikroba penghasilnya sering digunakan dalam mempercepat proses pembusukan selulosa secara biologis. Mikroba yang mampu menghasilkan selulase (selulolitik) sangat banyak tersebar di alam seperti kapang, aktinomisetes dan bakteri. Beberapa penelitian telah berhasil mengisolasi mikroba penghasil selulase dari berbagai tempat dan kondisi lingkungan. Sebanyak 70 isolat bakteri selulolitik berhasil diisolasi oleh dari sumber air panas Sungai Medang (Sari et al., 2012), Purwadaria et al., (2003) mencoba mebandingkan hasil isolasi bakteri dan kapang penghasil selulase yang diambil dari rayap. Sementara itu Yosmar et al., (2013) dan Khairiah et al., (2013), Yogyaswari et al., (2016) secara berturut-turut mengisolasi jamur dari ampas tebu, bakteri tanah gambut dan eksplorasi bakteri dari cairan rumen sapi. Enzim selulase yang berasal dari cendawan dahulu menjadi fokus dalam mendegradasi selulosa akan tetapi belakangan ini bakteri lebih sering digunakan karena pertumbuhannya yang lebih cepat bila dibandingkan dengan cendawan sehingga proses pendegradasian diharapkan dapat lebih singkat. (Li dan Gao 1997; Alam et al., 2004)

Penggunaan selulase saat ini cukup besar khususnya di bidang industri dan pertanian. Dalam industri penggunaan selulase untuk memproduksi glukosa yang erat kaitannya dengan industri alkohol, sirup glukosa, sirup fruktrosa dan dekstrosa (Indrawati, 2005). Di bidang pertanian penggunan selulase dilakukan bersama dengan mikroba penghasilnya dalam mendegradasi limbah pertanian berupa biomassa tanaman yang banyak mengandung selulosa. Dengan melalui berbagai tahapan dan proses biotransformasi bahan ini nantinya dapat menghasilkan pakan ternak, biogas, bioetanol dan pupuk organik. (Mtui 2009). Pada penelitian ini bertujuan untuk mengisolasi bakteri yang berasal dari tanah kandang sapi yang dianggap potensial karena terdapatnya sumber selulosa dari sisa rerumputan makan sapi.

BIOLOGI SEL (VOL 8 NO 1 EDISI JAN-JUN 2019 ISSN 2252-858X/E-ISSN 2541-1225) PAGE 22 


\section{METODE PENELITIAN}

Penelitian ini adalah jenis penelitian deskriptif kualitatif melalui pendekatan eksprimental yang bertujuan untuk mengisolasi bakteri penghasil selulase dan melihat aktivitas harian selulase tertinggi. Variabel penelitian ini adalah isolat bakteri dari asal tanah sapi

\section{Isolasi dan pemurnian bakteri selulolitik}

Sebanyak $1 \mathrm{~g}$ sampel tanah kebun karet IPB dimasukkan ke dalam plastik lalu ditambahkan larutan $\mathrm{NaCl}$ fisiologis $0,85 \%$, selanjutnya dilakukan pengenceran bertingkat dengan mengambil $1 \mathrm{ml}$ sampel dimasukkan ke dalam tabung reaksi yang berisi $9 \mathrm{ml} \mathrm{NaCl}$ fisiologis kemudian divortex untuk menghomogenkan sampai didapat kosentrasi $10^{-6}$. Pengenceran $10^{-4}, 10^{-5}, 10^{-6}$ masing-masing diambil $0,1 \mathrm{ml}$ lalu tanam dengan cara disebar pada media CMC secara merata dengan tabung penyebar dan dinkubasi pada suhu $37^{\circ} \mathrm{C}$ selama $48 \mathrm{jam}$. Koloni yang tumbuh dihitung jumlahnya, lalu diamati warna, bentuk, elevasi, dan permukaannya dan dimurnikan berdasarkan adanya zona bening yang mengelilingi koloni. Pemurnian koloni dilakukan dengan melakukan goresan kuadran pada media CMC, kemudian hasil pemurnian dibuat replikanya pada agar miring di tabung reaksi dan dinkubasi selama 48 jam pada suhu $37^{\circ} \mathrm{C}$.

\section{Analisis aktivitas bakteri penghasil selulase secara kualitatif}

Hasil pemurnian pada agar miring kemudian ditanam menggunakan jarum ose dengan menotolkan koloni bakteri ditengah-tengah cawan petri yang berisi media CMC dan diinkubasi selama 48 jam. Setelah koloni tumbuh dilakukan pewarnaan dengan menuangkan congored 1\% sampai koloni tenggelam dan ditunggu selama 15 menit. Larutan congored dibuang secara perlahan-lahan, setelah benar-benar bersih koloni bakteri dibilas dengan $\mathrm{NaCl}$ fisiologis sebanyak tiga kali dan disimpan dalam lemari pendingin selama 24 jam. Kemampuan bakteri dalam menghasilkan enzim selulase ditandai dengan terbentuknya zona bening disekitar koloni, zona bening yang terbentuk diukur untuk mendapatkan isolat yang potensial. Isolat yang dipilih untuk ditentukan aktivitas enzimnya merupakan isolat yang memiliki nilai indeks potensial terbesar. Nilai indeks selulolitik (IS) dapat ditentukan dengan menghitung zona bening yang terbentuk menggunakan perhitungan berikut

$$
\text { Indeks Selulotik }=\frac{\text { Diameter } \text { zona bening }- \text { Diameter } k \text { oloni }}{\text { Diameter koloni }}
$$

\section{Pengukuran aktivitas harian enzim selulolitik ekstrak kasar}

Pengujian aktivitas enzim ekstrak kasar dengan berdasarkan kadar glukosa. Kadar glukosa diukur menggunakan metode DNS (Miller, 1959). Poduksi enzim dimulai dengan menginokulasikan dua ose koloni bakteri yang telah diremajakan pada media CMC berumur 48 jam, ke dalam $100 \mathrm{ml}$ media CMC cair 1\% lalu diinkubasi dalam inkubator 
bergoyang dengan kecepatan 120 rpm selama 11 hari. Pemanenan enzim dilakukan setiap hari dengan menginokulasikan $5 \mathrm{ml}$ kultur bakteri ke dalam botol valcon steril, setelah itu supernatan yang mengandung enzim ekstrak kasar diperoleh dengan mensentrifugasi kultur bakteri tersebut pada kecepatan 6000 rpm selama 15 menit.

Uji aktivitas selulolitik sampel dilakukan dengan dimasukkan sebanyak $1 \mathrm{ml}$ substrat CMC 1\% ke tabung reaksi lalu ditambahkan $1 \mathrm{ml}$ larutan enzim ekstrak kasar kemudian divortex sampai homogen, yang diinkubasi pada suhu ruang selama 60 menit. Pada kontrol dan blanko dilakukan hal yang sama seperti pada sampel tetapi pada kontrol tanpa inkubasi pada suhu ruang selama 60 menit, sedangkan pada blanko tanpa enzim ekstrak kasar. Setelah itu ditambahkan $2 \mathrm{ml}$ pereaksi DNS dan divortex, kemudian dipanaskan pada suhu $100^{\circ} \mathrm{C}$ selama 10 menit, lalu didinginkan dan diukur nilai absorbansi sampel, kontrol dan blanko pada panjang gelombang $540 \mathrm{~nm}$ dengan spektofotometer. Pengukuran aktivitas enzim dilakukan sampai pada hari ke 11. Hasil nilai absorbansi (serapan) yang diperoleh kemudian dibuat grafik sehingga diperoleh nilai persamaan regresinya $y=a x+b$. Persamaan ini digunakan untuk menghitung nilai aktivitas gula pereduksi (x) dengan memasukkan nilai absorbansi sebagai nilai y. Aktivitas enzim selulolitik dapat dihitung dengan produk akhir yang dihasilkan yaitu glukosa dengan persamaan sebagai berikut.

$$
\frac{(x \text { sampel }-x \text { kontrol }) x \text { faktor pengenceran } x 1000}{T x \text { Berat molekul glukosa }}
$$

Keterangan

X sampel: kadar glukosa sampel,

$\mathrm{X}$ kontrol: kadar glukosa kontrol,

T: waktu inkubasi

\section{HASIL DAN PEMBAHASAN}

Sampel tanah yang digunakan dalam penelitian ini berasal dari tanah di sekitaran peternakan kandang sapi di lingkungan IPB. Pemilihan tempat pengambilan sampel berdasarkan perkiraan adanya isolat bakteri yang potensial dalam mendegradasi selulosa dikarenakan tanah banyak mengandung substrat selulosa lewat dedaunan yang jatuh dan pembusukan rumput yang menjadi makanan sapi. Berdasarkan hasil isolasi diperoleh tiga isolat bakteri yang mampu menghasilkan enzim selulase bersifat ekstraseluler dengan ditandai adanya zona bening pada media CMC $1 \%$ yang telah di tetesi pewarna congored (Gambar 1). Hasil pengukuran dar diameter zona bening yang dihasilkan oleh ketiga isolat memperlihatkan kemampuan yang berbeda-beda dalam menghasilkan selulase pada media CMC, berdasarkan hasil pengukuran indeks selulolitik diperoleh bahwa isolat KS 
0.1 memiliki nilai tertinggi dibandingkan dua isolat lainnya, sehingga pengukuran aktivitas enzim harian dilakukan pada isolat KS 0.1.

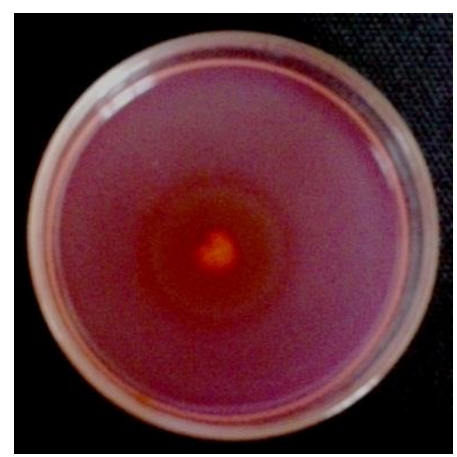

A

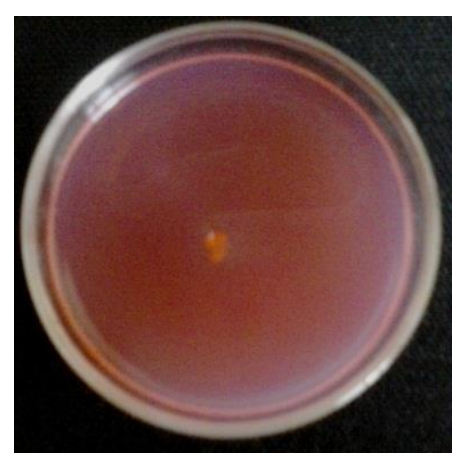

B

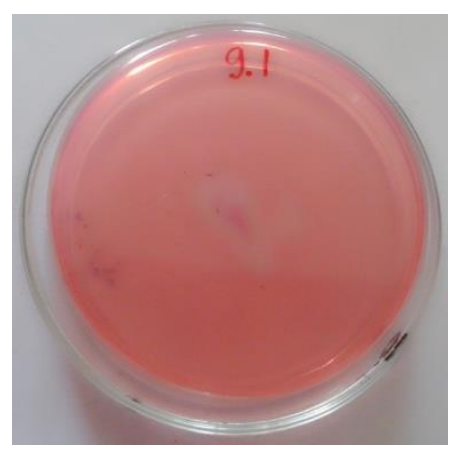

C

Gambar 1. Variasi zona bening yang dihasilkan isolat bakteri setelah penambahan Congo Red. (A) Isolat KS 0.1, (B) Isoat KS 0.7, (C) Isolat KS 9.1

Menurut Goto et al. (1992) selulosa amorf seperti yang tedapat pada media CMC sangat mudah dipecah oleh bakteri penghasil selulase. Menurut Enari (1983) terbentuknya zona bening pada sumber karbon CMC tersebut menunjukkan zona tempat terputusnya ikatan $\beta-1,4$ glikosida yang menghubungkan monomer D-glukosa pada CMC menjadi rantai amorf selulosa. Zona bening akan semakin jelas setelah penambahan Congo Red. Pewarna Congo Red $1 \%$ berfungsi untuk mengetahui besarnya zona bening yang muncul pada masing-masing isolat yang memiliki aktivitas selulase pada substrat spesifik akan menghasilkan zona bening di sekitar koloninya (Sazci et al., 1986). Zona bening yang dihasilkan oleh setiap bakteri selulolitik bervariasi karena setiap bakteri menghasilkan kompleks enzim selulase yang berbeda-beda, tergantung dari gen yang di miliki dan sumber karbon yang digunakan (Meryandini et al., 2009).

Tabel 1. Hasil pengukuran indeks potensial isolat bakteri selulolitik

\begin{tabular}{cccc}
\hline Isolat Bakteri & $\begin{array}{c}\text { Diameter koloni } \\
\text { bakteri }(\mathrm{cm})\end{array}$ & $\begin{array}{c}\text { Diameter zona bening } \\
(\mathrm{cm})\end{array}$ & Indeks selulolitik \\
\hline KS 0.1 & 0.75 & 1.89 & 1.33 \\
KS 0.7 & 0.75 & 1.5 & 1 \\
KS 9.1 & 0.75 & 1.4 & 0.86 \\
\hline
\end{tabular}

Pengukuran aktivitas enzim isolat KS 0.1 secara harian bertujuan untuk melihat waktu optimum dalam menghasilkan selulase dari, berdasarkan gambar 2 menunjukkan bahwa pada hari ke-1 kurva menunjukkan aktvitas tertinggi sebesar $0,001144 \mathrm{U} / \mathrm{ml}$ dan terus mengalami penurunan hingga pada pengamatan hari ke 4 yaitu $-0,001818677 \mathrm{U} / \mathrm{ml}$ hingga mencapai titik terendah pada hari ke 8 sebesar $-0,000141104 \mathrm{U} / \mathrm{ml}$. 


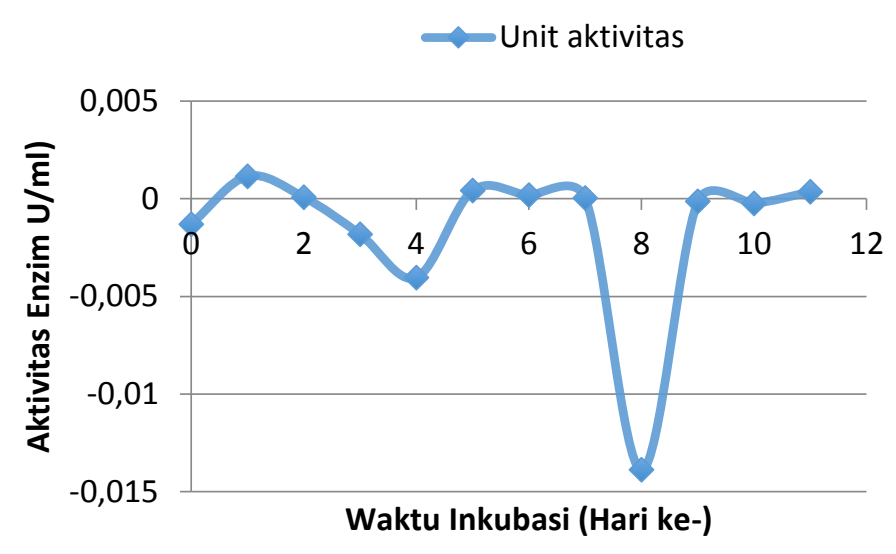

Gambar 2. Kurva Aktivitas Selulase

Hal ini menunjukkan bahwa terdapat perbedaan kemampuan isolat dalam memecah substrat perharinya. Kurva pada hari ke-0 memperlihatkan bahwa belum adanya enzim selulolitik yang dihasilkan sehingga substrat tidak dipecah menjadi molekul glukosa. Aktivitas enzim yang mengalami naik turun hal ini dapat disebabkan karena fase pertumbuhan sel yang berbeda. Pada saat aktivitas meningkat kemungkinan sel juga mengalami fase eksponensial sedangkan ketika terjadi penurunan aktivitas maka sel telah mencapai fase stasioner yang kemudian dilanjutkan fase kematian yang menyebabkan turunnya aktivas enzim yang dihasilkan selain itu juga sel pada dasarnya lebih menyukai substrat yang sederhana, ketika glukosa habis maka akan digunakan selulosa sebagai sumber karbonnya sehingga pemecahan ini menyebabkan glukosa menumpuk dan menghambat sisi sisi aktif enzim selulase (feedback inhibition) disamping itu juga terjadi represi sintesis selulase karena sel menggunakan glukosa sebagai sumber karbonnya yang berefek pada tidak diproduksinya enzim selulolitik (Abalos et al., 1997), disamping itu menurut Martina et al., (2002) pada saat fase stasioner dihasilkan juga enzim protease yang dapat merusak aktivitas dari enzim selulase.

\section{KESIMPULAN}

Dari penelitian ini diperoleh tiga isolat yang memiliki kemampuan menghasilkan selulase yaitu isolat KS 0.1, KS 0.7 dan KS 9.1 pada media agar CMC 1\%. Nilai indeks potensi selulolitik yang tertinggi terdapat pada isolat KS0.1 dengan nilai IS 1.33. Pengukuran aktivitas enzim ekstrak kasar dilakukan pada isolat KS 0.1 dengan nilai aktivitas selulase tertinggi diperoleh pada hari ke-1 sebesar 0,001144 U/ml dan terendah pada hari ke-8 -0,023939237. Penelitian berikutnya yang dapat yaitu melakukan karakterisasi enzim selulase berdasarkan pengaruh, $\mathrm{pH}$, temperatur, jenis substrat dan inhibitor. 


\section{DAFTAR PUSTAKA}

Abalos, J.M.F., Arribas, A.R., Garda, A.L., Santamaria, R.I. (1997). Effect of carbon source on the expression of celA1, a cellulase-encoding from Stretomyces halstedii JM8. FEMS Microbiol Letters 153:97-103.

Alam, M.Z., Manchulur, M.A., dan Anwar, M.N. (2004). Isolation Purification, Cellulolytic Characterization of by Enzyme Produced the Isolate Streptomyces omiyaensis. Pakistan Journal Biology Science. 7(10):1647-1653.

Enari, T.M., dan Paavola-Niku, M.L. (1987). Enzymatic of cellulose: Is the current of the mechanisms of hydrolysis valid CRC Crit. Rev. Biotechnology. 5:67-87.

Gerhartz, W. (1990). Enzymes in Industry: Production and Applications. VCH Verlagsgesellschaft mbH, D. 6940 Weinheim. 81-82.

Goto, M., Furukawa, K., Hayashida, S. (1992). An avicel-affinity site in an aviceldigesting exocellulase from Trichoderma viride mutant. Bioscience Biotechnology. 56(10): 1523-1528

Howard, R.L., Abotsi, E., J. van Rensburg E.L., and Howard, S. (2003). Lignocellulose Biotechnology: Issue of Bioconversion and Enzyme Production. African Journal of Biotech. 2(12):602-619.

Indrawati, I. dan S. Djajasupena. (2005). Isolasi Jamur dari Seresah dan Uji Keefektifannya dalam Penguraian Selulosa. Jurnal Ilmiah Biologi. 4(2):18 - 21.

Khairiah E, Khotimah S, Mulyadi A. Karakterisasi dan Kepadatan Bakteri Pendegradasi Selulosa pada Tanah Gambut di Desa Parit Banjar Kabupaten Pontianak. Jurnal Protobiont. 2(2):87-92.

Li, X., Gao, P. (1997). Isolation and Partial Properties of Cellulose-Decomposting strain of Cytophaga sp. LX-7 from soil. Journal of Applied Microbiology. 82:73-80.

Martina, A., Yuli, N., Sutisna, M. 2002. Optimasi Beberapa Faktor Fisik Terhadap Laju Degradasi Selulosa Kayu Albasia (Paraserianthes falcataria (L.) Nielsen dan Karboksimetilselulosa (CMC) secara Enzimatik oleh Jamur Jurnal Natur Indonesia. 4(2):156-163.

Meryandini, A., Widosari, W., Maranatha, B., Sunarti, T.C., Rachmania, N., Satria, H. (2009). Isolasi bakteri selulolitik dan karakterisasi enzimnya. Makara Sains. 13(1): 33-38.

Miller, G.L. (1959). Use of Dinitrosalicylic Acid Reagent for Determination of Reducing Sugar. Analytical Chemistry. 31(3): 426-428.

Mtui, Y.S. (2009). Recent Advances in Pretreatment of Lignocellulosic Wastes and Production of Value Added Products. African Journal of Biotechnology.8(8):1398-1415.

Purwadaria, T., Marbun, P.A., Sinurat, A.P., Ketaren, P.P. (2003). Perbandingan Aktivitas Enzim Selulase dari Bakteri dan Kapang Hasil Isolasi dari Rayap. Jurnal Ilmu Ternak dan Veteriner. 8(4):213-219. 
Saha, B.C. (2004). Lignocellulose Biodegradation and Application in Biotechnology. US Government Work. American Chemical Society. 2-14.

Sari, U.M., Nurmiati, Agustien, A. (2012). Penapisan dan Karakterisasi Bakteri Selulolitik Termofilik Sumber Air Panas Sungai Medang, Kerinci, Jambi. Jurnal Biologi Universitas Andalas. 1(2):166-171.

Sazci, A., Radford, A., Erenler, K. (1986). Detection of cellulolytic fungi by using Congo red as an indicator:a comparative study with the dinitrosalicyclic acid reagent method. Journal of Applied Bacteriology. 61. 559-562.

Yogyaswari, S.A., Rukmi, M.G.I., Ruharjo, B. (2016). Eksplorasi Bakteri Selulolitik dari Cairan Rumen Sapi Peranakan Fries Holland (PFH) dan Limousine Peranakan Ongole (LIMPO). Jurnal Biologi. 5(4):70-80. 